\title{
Scope and strategies for genetic improvement in vegetable crop-plants under high temperature and abiotic stressed climate of Rajasthan: A gap analysis
}

\section{DK Samadia \& SM Haldhar}

Journal of Agriculture and Ecology

\section{Journal of Agriculture}

ISSN: 2456-9410

Volume: 8

Journal of Agriculture and Ecology (2019) 8: 1-18 http://doi.org/10.53911/JAE.2019.8201 


\title{
Scope and strategies for genetic improvement in vegetable crop-plants under high temperature and abiotic stressed climate of Rajasthan: A gap analysis
}

\author{
DK Samadia $\square \&$ SM Haldhar \\ ICAR-Central Institute for Arid Horticulture, Sri Ganganagar Highway, Beechwal Industrial Area, \\ Bikaner (Rajasthan)-334006, India \\ Corresponding author: DK Samadia, E-mail: samadiadk@yahoo.com
}

\section{Article Info \\ Article history \\ Received: 25 April 2019 \\ Accepted: 20 July 2019 \\ Available online: 5 August 2019}

Key Words: Kachri, snap melon, mateera, khejri, arid vegetable, hot arid climate, Rajasthan, India.

\begin{abstract}
Un-exploited, under-scored and native crop-plants of horticultural significance have enormous potential in providing nutrition rich food and social security to inhabitants of desert and tribal areas of the north-western India. While conducting surveys and explorations for horticultural perspective, and examining distinctness of hot arid, semi-arid and sub-humid climate of Rajasthan from 1994 - 2004, it was concluded that un-availability of apposite crop-genotypes and production techniques are two major constraints which limiting dry-land vegetable promotion. Traditionally, kachri, kakadia, mateera, tinda and guar-phali ensuring native vegetable produce, besides, khejri (Prosopis cineraria) is playing vital role in long-established mixed farming systems of arid farm-lands. In addition, native land-races of kakri, kheera, kundru, kakoda, cowpea, sem-phali and okra are monsoon supported vegetable harvest in the semi-arid and tribal areas of state. Establishment of NRCAH during 1993 at Bikaner supported systematic research on collection, characterization and conservation of native vegetable crop-plants as regional diversity, and further work was intensified on germplasm utilization in particular for high temperature and abiotic stresses tolerant breeding. The cropgenotype studies over 45 vegetables at CIAH demonstrated that there is magnificent scope in obtaining higher marketable and quality yields, provided better and trait-specific genotypes and production site management (HBCPSMA) as integrated concept for vegetable cultivation under hot arid environment. Thus, conserving germplasm, developing genotypes and newer technological advancement in arid vegetables is an advantage towards better nutrition and farmer's income under dry-land conditions.
\end{abstract}

Copyright (C2019 Samadia \& Haldhar, This is an open access article published under the terms of the Creative Commons Attribution License, which permits unrestricted use, distribution, and reproduction in any medium, provided the original work is properly cited.

Preferred citation: Samadia DK \& Haldhar SM. 2019. Scope and strategies for genetic improvement in vegetable crop-plants under high temperature and abiotic stressed climate of Rajasthan: A gap analysis. Journal of Agriculture and Ecology, 8: 1-18; http://doi.org/10.53911/JAE.2019.8201.

\section{Introduction}

Horticultural crop-plant produce and their products are rich sources of carbohydrate, fibre, protein, nutrients, vitamins and anti- oxidants, and thus valued for nutritious diet. In India, about 175 types of crop-plants are used for fresh and culinary vegetable purposes. The vegetable production in the country is largely un-even and concentrated mostly into the few 
states and areas where the agro-climate is favourable and mild for their higher production. In addition, emphasis is only on the few numbers of vegetables and that too are grown with better irrigation and high-input facilities (Samadia, 2018; Samadia and Haldhar, 2018 and More et al., 2018).

\section{Scope for dry-land vegetables}

Production and marketing of diverse, non-conventional and high-value vegetables is now seen as key to generate more income per unit area and round the year, and also reducing poverty amongst small farmers in developing countries. India is the second largest producer of vegetables and the share is about $15 \%$ of the world production. On the other-side, its distance from the world's number one (China) is quite large and this wide-gap arises several questions on productivity levels of vegetables in the Indian fields, types and quality of cropgenotypes and seed / planting material being made available, adoption level of technologies, management and utilization of resources at production sites with much climatic variability (Samadia 2007; Samadia 2016). With the on-set of $21^{\text {st }}$ century, there is spectacular change in the consumption pattern of vegetables and promotion of nutritious diet in India is getting momentum. The increased vegetable consumption is further expected to enhance, and it is because of the rising income levels, changing pattern of dietary mix, nutrition and health awareness, ease and round the year availability. Further, the present productivity levels of many vegetables is lower than the world average, and also areas of production and supply-chain for every-part of the country is not defined, and therefore, it is difficult to meet-out the much increasing demand within time-frame without intensification, diversification, integration and management of resource based production sites for systematic vegetable cultivation at the variable climatic regions (More \& Samadia 2008).

To meet-out the ever increasing vegetable demand and utilization of indigenous resources, now, there is utmost need for massive and integrated efforts, and it should be firstly by developing high yielding crop-genotypes suited to the prevailing situations of the defined agro-climatic zone and resource based production techniques under climatic variability. Second is through systematic use of the native resources such as varied land-forms and under-scored horticultural crop-plants of vegetable potentialities. In this way, the desert, arid, semi-arid and tribal areas of Rajasthan state is un-tapped and vast land resource where several well-liked and adapted crop-plants of horticultural significant can be exploited for organized vegetable cultivation (Samadia et al. 2004; Samadia 2007) adopting production site management approaches (Samadia 2016).

\section{Crop-production factor analysis for dry- land vegetables}

In-spite of the environmental, bio-physical and resources constraints in most of the parts of Rajasthan, even the state can classified into three distinct agro-climatic zones namely hot arid, semiarid and sub-humid for the horticultural perspective. These three geographical diverse zones have excellent vegetable production potential with wide range of crop-plants and varied opportunities of resources utilization. The 
extremes of high (March-October) and low (December-January) temperature conditions intogether associated abiotic factors in the arid and semi-arid areas limiting the choice of crops and their genotypes and quality of produce, and on the other-side, tribal dominating sub-humid zone has unbelievable strength for dry-land vegetables. Here, vegetable intensification with adaptive and native crop-plant species is in general found to be the most appropriate and stable under dry-land situations of the state that receiving 150-650 mm precipitation, and encountering problems from abiotic factors owing to climatic variability, erratic rains, extremes of temperature, drought, frost, hot and cold winds, soil and water quality (Samadia \& Haldhar 2017). Out of 9-21 mean rainy days/annum in these three variable zones of the state, much of rains often comes in only a few (15) heavy events during the monsoon season (JuneSeptember) and is scanty and un-certain. In kharif, higher temperature $\left(35-42^{\circ} \mathrm{C}\right)$ range and prolonged drought periods (15-35 days) together sandy soil creates an environment where few crops can survive under rainfed situations and thus, native crop-plants both annual and perennial have vital role for food and fodder.

Here, winter is dry and minimum temperature fluctuates around $4-10^{\circ} \mathrm{C}$ during December-January and some-times it prolonged to February. Most of the years, low temperature situations dips-down below freezing $\left(-1\right.$ to $\left.-6^{0} \mathrm{C}\right)$ and occurrence of frost is frequent in hot arid zone. Where as sub-humid tribal area is free from winter adversity and frost. The distinct and variability winter temperature determinates sowing-time and offers scope for wide range of vegetable crops. In the north-western part of the state, March-October months are hot, dry and sunny with continuity of high temperatures around $38^{0} \mathrm{C}$ for prolonged period and resulted to excessive evapo-transpiration from crop-plants and soil-surface. In hot summers, maximum temperature in the May-June is mostly above $40^{\circ} \mathrm{C}$ in the east to $42^{\circ} \mathrm{C}$ in the western area of the state. But it is very common to experiences extremes of temperature $42-47$ and $45-50^{\circ} \mathrm{C}$ for the numbers of days (21-28 days), respectively and during these days, night temperature range $31-35^{\circ} \mathrm{C}$ is also very high.

The sand-dunes field soil is coarse texture, poor in fertility and water retention capacity. The hot arid zone encounters strong winds and fertile top-soil, sand and other fine particles is continuing blows away leading behind the coarse substrate poor in nutrients, and thus affecting production potentials of farm-land. The problem becomes more serious in the fields which have to ploughed in the summer months, and remain without any protective plant cover till the on-set of monsoon rains. The crop-plants also get damaged through sand blasting on seedlings, leaves, stem, buds, flowers and tender fruits during the heat waves and dusty wind storms (LOO and ANDHI). The seedlings or young plants buried under sand and vine plants disturbed badly. During the peak summer, there is heavy adverse effect of heat stresses on the growth of vegetable crops and quality of produce, and some times whole plants burns owing to heating.

In vast-spread traditional farming systems of arid and semi-arid farm-lands, mixed cropping of pearl-millet (bajra), cluster bean, moth bean, moong bean or cowpea is dominating in millions of hectare area and the indigenous cucurbits such as kachri, kakadia, mateera, tinda and arya-kakri are the rescue vegetables. In addition, native perennial tree-plants such as khejri, ker, lasora, kumat, jharber, bordi, khimp, phog, guarpatha and tumba have horticultural attraction, ensuring nutrition rich food product and providing subsistence income under rainfed conditions to the desert dwellers. Likewise in sub-humid and tribal area, mixed cropping with maize, urd bean, moong 
bean, cowpea, cluster bean or pigeon-pea is performed during the kharif and in which native forms/ landraces of mat-kachar, phut, arya-kakri, wanga-kakri, chikan-kakri, kundru, kakoda, okra, bakala-phali, sem-phali, komba-phali and conchphali are the supporting vegetables to the local inhabitants.

Here, systematic vegetable cultivation is very limited and productivity levels is too low, and it is primarily due to un-availability of desirable crop-plant genotypes suited to the environmentally stressed production sites, un-availability of quality seed-planting materials of recommended cropgenotypes for growing with varying situations of the dry-lands, and lack of crop-genotype-climatic matching production techniques. Therefore, there are essentially two complementary requirements for obtaining higher and marketable quality vegetable production and productivity i.e. improvement in genetic make-up of prioritized crops and development of favourable microclimate at production sites (Samadia 2016). The Indian arid zone can grow a large number of vegetable crops compared to any hot desert of the world (Samadia et al. 2004). Some of well recognized and potential vegetable crop-plants have been identified for diversification of dry-land horticulture and are given (table-1). Based on the region specific surveys in the hot arid, semi-arid and tribal areas of Rajasthan and Gujarat and field research work over the 25 years at CIAH, the extent of restrictions and opportunities have been assessed in respect to the horticultural promotion and recommendations are carved out for dry-land vegetables. In addition, innovative and resource based conceptual production approaches have been suggested for cultivating vegetables with rainfed, limited or assured irrigated conditions under three distinct climatic zones of Rajasthan. The importance of eco-significance native trees / shrubs having potentialities of regional, traditional and minor vegetables in fresh, dehydrated or processed forms have also been highlighted for promoting resource based native or intensive cropping models under the climatic variability. By incorporating the selected, un-exploited and indigenous floras at the crop production sites as component of wind-break, boundary-side, biofence, hedge-row, field-divider, strip-block or planting model would not only helping in the creation of favourable micro-climate for vegetable cropping sequences but also ensure regular income-flow from these socio-welfare species as monsoon supported harvest (Samadia \& Haldhar 2017).

Table 1. Prioritized vegetable crop-plants for dry-land of Rajasthan state

\begin{tabular}{ll}
\hline \multicolumn{1}{c}{ Group } & Crop-plants \\
\hline Cucurbitaceous & Kachri (Cucumis melo var. callosus/ agrestis), snap melon (Cucumis melo var. \\
& momordica), kakri (Cucumis melo var. common / utilissimus/ fluxuosus/ acidulus), \\
& muskmelon (Cucumis melo var. inodorous/ cantaloupensis), mateera/ watermelon \\
& (Citrullus lanatus), round melon/ tinda (Praecitrullus fistulosus), bottle gourd \\
& (Lagenaria siceraria), ridge gourd (Luffa acutangula), sponge gourd (Luffa \\
& cylindrica), ivy gourd/ kundru (Coccinia indica), bitter gourd (Momordica \\
& charantia), spiny gourd/ kakoda (Momordica dioica) and pumpkins (Cucurbita \\
& spp) \\
& Cluster bean/ guarphali (Cyamopsis tetragonoloba), cowpea (Vigna unguiculata), \\
& Sem, Dolichos/ Indian bean (Lablab purpureus), sword bean/ kombaphali \\
& (Canvalia gladiata), pea (Pisum sativum)
\end{tabular}


Solanaceous Chilli (Capsicum annum), brinjal (Solanum melongena), tomato (Lycopersicon esculentum)

Cole crops Cabbage (Brassica oleracea var capitata), cauliflower (Brassica oleracea var. botrytis), knol-khol (Brassica oleracea var. caulorapa)

Bulbous Onion (Allium cepa), garlic (Allium sativum)

Root crops Radish (Raphanus sativus), carrot (Daucus carota)

Okra Okra (Abelmoschus esculentus)

Leafy Methi (Trigonella foenumgraecum and T. corniculata), palak/ spinach (Beta vulgaris/ Spinacia oleracea), coriander (Coriandum sativum), chaulai (Amaranthus spp), bathua (Chenopodium spp.), sowa (Anethum sowa)

Perennials Khejri/ sangri (Prosopis cineraria), drumstick / sehjan (Moringa oleifera), Indian aloe/ guarpatha (Aloe barbadensis), phog (Callgonum polygonoides), khimp (Laptadenia pyrotechnica), ker (Capparis decidua), lasora / gunda (Cordia myxa), kumat (Acacia senagal), khumbi (desert mushroom)

Owing to variable and to some extent manageable climatic conditions, availability of limited irrigation water facilities and potentialities of diverse types for production system (rainfed, limited or assured irrigation) in the vast spread arid farm-land, a careful selection of crop-plants and their genotypes for specific zone could be gainful for the success in vegetable upgrading. The peculiar arid environmental conditions impart unique quality in kachri, snap melon, mateera, bottle gourd, muskmelon, chilli and seed spices. An enormous scope to promote large-scale seed production in cucurbits, tomato, chilli, brinjal, okra, early cauliflower, pea, cluster bean, cowpea, Indian bean, palak, methi, coriander, cumin, and truck gardening for distance markets in particular to the cole crops, onion, carrot, melons and chillies is do exists with the irrigated farm-land. The indigenous products of khejri, ker, kachri and kakadia can be exploited for processing industry. Dry vegetables products have lot of market potential as concentrated vegetables (e.g. leaves of Nagori paan-methi, sehjan). The conditions of high temperature and low humidity helps in solardrying and it is already in practice for the leaves of Nagori paan-methi, pods of khejri (sangri) and cluster bean and fruits of kachri, kakadia, tinda and chillies (Samadia et. al 2004; Samadia 2007;
More \& Samadia 2007) adopting low-cost and movable tunnel or tent type structure with polythene and insect-proof net sheet as covering material. In dry-lands, the existing productivity and quality production in majority of vegetable crop-plants can enhanced by improving genetic make-up, adopting production techniques and innovative practices under the integrated approaches as crop-genotype-environment accepting. Here, special attention is needed to exploit native crop-plant genetic resources of horticultural significance for developing intensive, stable and viable vegetable industry. For this, systematic breeding approaches on targeted crops is needed on high precedence to develop desirable genotypes with multiple-use attributes including adaptability under extremes of temperature and abiotic stressed situations and processing. In addition, marketable quality, productivity and production of recommended crop-genotypes can be further improved when due consideration given to in-situ rain-water harvesting, management of limited rain / irrigation water and adopting improved techniques and practices in a strategic manner with innovative concept - Horticulture based crop production site management approaches and model planting of khejri or mango (HBCPSMA, Samadia 2016). 
Genetic improvement and varietal development in dry-land vegetables

The concerted germplasm utilization and improvement programmes in India during the $20^{\text {th }}$ century resulted to development of good number of high yielding varieties and hybrids in potential vegetables suited to the different agro-climatic zones including dry-lands of Rajasthan state. The increased production in selected vegetable crops from 1960 to 1990 period in the country is mainly because of availability of open-pollinated and hybrid seed of recommended varieties and it was pre-dominantly by public institutions and to some extent from private agencies. But in recent two decade, the varietal seed-chain is largely running by private / multi-national sector and it is owing to high seed-cost in preferred vegetables and these are being popularized at favourable climatic zones. For dry-lands of Rajasthan, the scenario of germplasm collection and utilization from 1960 to 1990 period is very impressive in developing varieties of vegetable crops. A good numbers of varieties in watermelon (Durgapura Meetha, Durgapura Kesar), muskmelon (Durgapura Madhu), tinda (Bikaneri Green), ridge gourd (Salumber-8), onion (Udaipur-101, Udaipur-102), palak (Jobner Green), methi (RMT-1) and cluster bean (Durga Bahar) were recommended and these were very popular due to its seed-chain by the institutions (Personnel communications with the workers - Dr. O. P. Pareek, Dr. Premnath, Dr. R. C. Khandelwal, Dr. R. S. Dhaka). Later on, some more varieties were identified in watermelon (Durgapura Lal, RW-187-2), muskmelon (RM-43, MHY-3, MHY-5, RM-50), bottle gourd (DBG-5), long melon (DLM-1, DLM-28), cluster bean (M83), cowpea (RCV-7, RCV-10), chilli ( $\mathrm{RCH}-1$ ), onion (RO-1, RO-59), garlic (DG-1) and pea (RP$3, \mathrm{RPV}-7)$ from state universities and included in packages of vegetable cultivation.
A good amount of native vegetable genetic resources in particular to cucurbits, cluster bean, cowpea, pea, beans, chilli, brinjal, palak, methi, coriander, cauliflower, okra, onion and garlic was explored from 1960 to 2005 as genes for drought tolerant, quality of produce, early maturity, short duration and prolific bearing. This crop-specific germplasm was collected from arid, semi-arid and tribal areas of Rajasthan, and also near by state tribal areas of north-western India (Madhya Pradesh and Gujarat) by the national institutions such as NBPGR, IIHR, IARI, IIVR, PAU and HAU, and utilized in their breeding programmes for developing varieties. At IIHR only, utilization of such germplasm collections from arid, semi-arid and tribal areas of Rajasthan and Gujarat resulted to release of number of varieties like Arka Manik (watermelon), Arka Rajhans (muskmelon), Arka tinda (round melon), Arka Harit (bitter gourd), Arka Suryamuki (pumpkin) and Goma Manjari (cluster bean) and these are still popular and widely adopted. In this way, a wide spectrum of native vegetable cropplant genetic diversity is do exists, reported, collected and conserved in cucurbits, chilli, brinjal, okra, cluster bean, beans, cauliflower, onion, garlic and minor tubers from dry-lands of north-western parts of India. But not yet systematic exploited for developing trait or region specific genotypes to commercialize these crops under the extremes of high temperature $\left(45-50^{\circ} \mathrm{C}\right)$, abiotic stressed and resource poor arid environment, and also combating climatic extremeness through gene-pool utilization for vegetable cultivation in the three distinct zones of the state. For full-filling vegetable demands under climatic uncertainty in the country, the most important need is to have strategic and integrated efforts for breeding need-based varieties / traitspecific or value-added genotypes and seed-chain of recommended crop-genotypes suited to the production sites of the defined zone. Since, this is 
one of the most efficient and rapid method uses for increasing production world-wide in native and prioritized vegetables.

Despite of a wide range of vegetable varietal wealth under national net-work and their zonal recommendations, the requisite production, productivity and quality of produce is yet not improved significantly in dry-lands. There are very few numbers of crop-genotypes with wider adaptability for marketable yield potentials with the varying environmental situations, and doing well only under favourable sub-humid zone of the state. However, much research work to develop varieties or trait-specific genotype is needed in native and un-exploited crop-plants of regional significance, and also in adaptive and potential vegetables for cultivation in the non-conventional areas with arid to semi-arid sub-tropic climate that encountering problems from extremes of high temperature and drought situations (More \& Samadia 2007; Haldhar et al. 2018a). While assessing agro-climate of the state in 1994-1997, it was concluded that environmental constrains viz., low and erratic rains, extremes of high and low temperature and aridity conditions and unavailability of appropriate crop-genotypes and production techniques are the limiting factors in thoughtful adoption of vegetable cultivation. With the establishment of national centre at Bikaner in 1993, the first five year research project on vegetable was for germplasm collection, conservation and utilization with the native cropplants having horticultural and drought tolerating significance. Traditionally, kachri (Cucumis melo var. callosus / agrestis), kakadia / snap melon (Cucumis melo var. momordica), mateera - a drought hardy watermelon (Citrullus lanatus), tinda (Praecitrullus fistulosus) and guar (Cyamopsis tetragonoloba) is grown mixed under rainfed situations. Besides, khejri (Prosopis cineraria) is perennial tree and have vital role in long-established farming systems, and its pods are vegetable use (sangri). The crop-genotype evaluation and performance studies on 45 vegetables from 1995-2005 at CIAH, Bikaner demonstrated that there is tremendous scope in obtaining better marketable yields in cucurbits, chilli, brinjal, tomato, pea, beans, cluster bean, okra, onion, garlic, radish, carrot, cole, leafy and several socio-eco-significance crop-plants, provided trait-specific varieties suited to the prevailing conditions of dry-land.

The types of vegetable significance cropplants found growing in arid and semi-arid area are quite distinctly different presumably due to eco-adaptations and climatic variability in the state. The north-western part of arid region grows some typical cucurbitaceous and under-scored vegetable potential crop-plants. The Aravalli mountain range separates desert eco-system of arid zone from the eastern semi-arid to sub-humid areas, and a wide range of vegetable significance crops are in the traditional farming. Under the drylands, rich genetic variability do exists in particular to Citrullus, Cucumis, gourds, okra, onion and other native crop-plants of horticultural exploitation. Regular collection of germplasm variability and crop-varieties, their evaluation and selections contributed maximum in vegetable improvement, diversification and production. Thus, collection, selection and utilization of genetic material would continue to be the best, dependable and desirable approach for vegetable improvement under the abiotic stressed situations of dry-land.

To develop profitable vegetable farming under dry-lands, first-time strategic work-plan on germplasm collection and improvement was formulated at NRCAH / CIAH, Bikaner and started during 1994. In the first five years (19941999) period, main emphasis was on indigenous crops of Citrullus and Cucumis group. Later on prioritized crops such as chilli, muskmelon, 
gourds, brinjal and beans were incorporated considering the requirement of superior genotypes for cultivation under dry-land conditions. Mission mode work on the improvement in khejri was started from 2001 and at same time work on other native perennial crop-plants was also intensified. Intensive breeding work for heat tolerant in round melon, bottle gourd, muskmelon, tomato and brinjal was taken in 2007. Breeding for improvement in marketable quality yields and productivity is a continuous nature and thus, vegetable research work-plan was modified during 2010 and focus was given to heat and drought tolerant varietal development in prioritized crops.

\section{(a) Conservation and maintenance of arid vegetable germplasm for breeding use}

Landraces and local types / cultivars are source of genes for stresses tolerant, adaptability, quality and yield and therefore, collection and characterization is the pre-requisite for the potentially utilization of genetic resources. Realizing the importance of vegetable crops in the hot arid region of north-western parts of India, systematic collection of germplasm was started since 1994 at Bikaner under the mission mode of the NRCAH, NATP on plant bio-diversity and institute programmes of CIAH. From 1994 to 2005 period, several crop-specific and multi-crop explorations were conducted for surveys and collection of vegetable germplasm from arid, semi-arid and tribal areas of Rajasthan and Gujarat, and also augmentation of germplasm in targeted crops was done for varieties and lines from the national net-work including NBPGR and AICRP (VC) system (Pareek et al. 1999; Samadia 2003). For dry-land vegetable germplasm, the institute is primarily concentrating on conservation, utilization and maintenance of the indigenous crop-plants diversity. The research work done under management of genetic resource programme is classified as surveys and explorations for the crop inventory and germplasm collection from variability pockets; characterization and categorization of germplasm for long-term conservation; evaluation, identification, purification and advancement of germplasm lines / material and use in improvement programme; large-scale testing of selected / developed progenies, performance studies for uniformity and stability of lines and varietal trials and testing of genotypes at farmer's field and development of seed-chain of recommended varieties. The valuation of nationallevel material, re-visiting and re-generation of developed material and its maintenance is also regular research work-plan for conservation and intensive utilization of the material for breeding trait-specific lines / value-added genotypes and varieties in targeted vegetables under hot arid environment at CIAH, Bikaner (Anon. 2005; Anon. 1994- 2018).

For gap-analysis on genetic resource management in dry-land vegetables, the research work done at the institute was compiled and data base is developed (table-2). From 1994 to 2008, a total 1725 accessions were collected and characterized and out of them 1060 germplasm were deposited in NGB at NBPGR for long-term conservation. The vegetable germplasm either collected by CIAH or assembled from NBPGR-RS under NATP (PBD) or national net-works were evaluated for use in improvement programme at Bikaner. On characterization and evaluation under the extremes of hot arid environment, vegetable crop-plant germplasm exhibited wide range of variability for agro-morphological traits, flowering and fruiting behavior, maturity, yield and quality contributing characters, besides resistant or tolerant to abiotic and biotic stresses (Samadia 2006; Samadia 2007; Samadia 2010; Samadia 2011; Samadia 2014; Khan \& Samadia 2012). For dry-land vegetable genetic resources studies, major emphasis was given to kachri (591), snap 
melon (120), kakri (32), muskmelon (74), mateera (217), tinda (26), gourds (156), chilli (217), brinjal (78), tomato (125), cluster bean and beans (90) characterization and utilization to identify material based on their potentiality under hot arid environment. Based on intensive evaluation and performance studies over the seasons and years (1994-2016), potential vegetable crops germplasm were identified and developed genetic material from the basic gene-pool is maintained as active breeding lines (500) for use in improvement programmes. The maintained material is comprised of kachri (68), snap melon (65), mateera (65), muskmelon (60), round melon (10), kakri (18), bottle gourd (20), ridge gourd (20), sponge gourd (15), bitter gourd (4), chillies (45), brinjal (30), tomato (14), khejri (15), India bean (30), sword bean (01), velvet bean (01), cluster bean (02) and others (15) including perennial vegetables (Samadia 2016; Haldhar et al. 2018b).

Table 2. Collection, conservation and utilization of vegetable genetic resource at CIAH, Bikaner

\begin{tabular}{|c|c|c|c|c|}
\hline \multirow{2}{*}{$\begin{array}{l}\text { Common, English or } \\
\text { Scientific name }\end{array}$} & \multicolumn{3}{|c|}{ No. of germplasm under PGRM, CIAH } & \multirow{2}{*}{$\begin{array}{l}\text { Year of evaluation, re-visits for } \\
\text { utilization and / or re-generation } \\
\text { of active genetic material for } \\
\text { maintenance and utilization }\end{array}$} \\
\hline & $\begin{array}{c}\text { Collection } \\
\& \\
\text { evaluation }\end{array}$ & $\begin{array}{c}\text { Conservation } \\
\text { in NBPGR }\end{array}$ & $\begin{array}{l}\text { Breeding } \\
\text { lines }\end{array}$ & \\
\hline Kachri & 591 & 528 & 68 & $\begin{array}{l}\text { 1995, 1996, 1997, 2000, } \\
\text { 2001, 2003, } 2011\end{array}$ \\
\hline Snap melon/ kakadia & 120 & 53 & 65 & $\begin{array}{l}1995,1996,1997,2000, \\
2003,2004,2012\end{array}$ \\
\hline Muskmelon & 74 & 55 & 60 & $1997,1998,2001,2007,2008$ \\
\hline $\begin{array}{l}\text { Kakri/Arya/Long } \\
\text { melon }\end{array}$ & 32 & 15 & 18 & $\begin{array}{l}\text { 1996, 1997, 2002, 2003, } \\
2006,2015,2016\end{array}$ \\
\hline Cucumber & 12 & - & 01 & 1997, 1998, 2000, 2016 \\
\hline Cucumis prophaterum & 02 & - & - & 2000 \\
\hline Cucumis trigonus & 01 & - & - & 2000 \\
\hline Cucumis hardwickii & 11 & - & - & 2000 \\
\hline Tumba & 05 & 01 & 01 & $2000,2008,2009$ \\
\hline Mateera/ watermelon & 217 & 64 & 65 & $\begin{array}{l}1995, \quad 1996, \quad 1997, \quad 2002, \\
2003,2009,2010\end{array}$ \\
\hline Tinda/ round melon & 26 & 14 & 10 & $\begin{array}{l}1995, \quad 1996, \quad 1997, \\
2003,2007,2017\end{array}$ \\
\hline Bottle gourd & 85 & 20 & 20 & $\begin{array}{l}\text { 1996, 1997, 2003, 2007, } \\
\text { 2008, } 2009\end{array}$ \\
\hline Ridge gourd & 30 & 20 & 20 & 1997, 1998, 2003, 2004, 2015 \\
\hline Satputia torai & 01 & 01 & - & 2000 \\
\hline Sponge gourd & 25 & 15 & 15 & 1997, 1998, 2003, 2004, 2014 \\
\hline Bitter gourd & 13 & 03 & 04 & $1997,1998,2003,2004,2013$ \\
\hline Spiny gourd/ kakoda & 01 & - & $01 \mathrm{FGB}$ & $1997,2002,2015,2017$ \\
\hline Ivy gourd/ kundru & 01 & - & $01 \mathrm{FGB}$ & 2001, 2002, 2010, 2012, 2015 \\
\hline Pumpkin & 04 & - & 04 & $1997,2003,2004$ \\
\hline Summer squash & 01 & - & - & 2009,2010 \\
\hline Chillies & 217 & 202 & 45 & $\begin{array}{l}\text { 1999, 2000, 2002, 2003, } \\
\text { 2008, } 2009\end{array}$ \\
\hline Brinjal & 78 & 25 & 30 & 1998, 2002, 2003, 2008, 2009 \\
\hline
\end{tabular}




\begin{tabular}{|c|c|c|c|c|}
\hline Tomato & 125 & 14 & 14 & 1998, 2002, 2003, 2008, 2009 \\
\hline $\begin{array}{l}\text { Cluster bean / } \\
\text { guarphali }\end{array}$ & 20 & 01 & 02 & 1995, 1996, 1997, 2011 \\
\hline Indian bean/ semphali & 45 & 30 & 30 & 1998, 2001, 2002, 2010, 2011 \\
\hline $\begin{array}{l}\text { Sword bean/ } \\
\text { kombaphali }\end{array}$ & 02 & 01 & 01 & $2001,2002,2003,2009,2016$ \\
\hline $\begin{array}{l}\text { Velvet bean/ } \\
\text { conchphali }\end{array}$ & 01 & - & 01 & 2009,2010 \\
\hline Cowpe / chavlaphali & 08 & - & 03 & $\begin{array}{l}1997, \quad 1998, \quad 2001, \quad 2002, \\
2004,2017,2018\end{array}$ \\
\hline Pea & 04 & - & - & 1997,1998 \\
\hline Okra & 01 & - & - & 1997,1998 \\
\hline Khejri/ sangri & 16 & - & 15 FGB & $\begin{array}{l}1995, \quad 2000,2001, \quad 2002, \\
2010,2011,2012\end{array}$ \\
\hline Drum-stick/ sehjan & 05 & - & 01 FGB & $\begin{array}{l}1995-97,2002-07,2009-12, \\
2014-17\end{array}$ \\
\hline $\begin{array}{l}\text { Curry-leaf/ meetha- } \\
\text { neem }\end{array}$ & 01 & - & 01 FGB & 1998, 2000, 2015, 2017 \\
\hline Indian aloe/ guarpatha & 03 & - & 03 FGB & 1994, 1995, 2002, 2008, 2017 \\
\hline Palak & 03 & - & 01 & $\begin{array}{l}1995-97, \quad 2002-04, \\
2015,2016,2017\end{array}$ \\
\hline Methi/ kasuri-methi & 02 & - & 02 & $2004,2005,2008,2015$ \\
\hline Sowa/ dill & 03 & - & - & 2004,2005 \\
\hline Ajowan & 02 & - & - & 2004,2005 \\
\hline Bathua & 01 & - & 01 & 2012,2013 \\
\hline Cabbage & 04 & - & - & 1998, 1999 \\
\hline Cauliflower & 02 & - & - & 1998, 1999 \\
\hline Knol-khol & 02 & - & - & 1998, 1999 \\
\hline Radish & 02 & - & - & 1998, 1999 \\
\hline \multirow[t]{2}{*}{ Carrot } & 01 & - & 01 & $1998,2012,2013$ \\
\hline & 02 & - & - & 1998, 1999 \\
\hline Garlic & 01 & - & - & 1998, 1999 \\
\hline
\end{tabular}

(b) Utilization of arid vegetable genetic resource for breeding varieties

To promote organized vegetable cultivation under high temperature and water stressed dry-lands, the systematic breeding and varietal development work-plans were formulated first time as PI of project and stated in 1994. During the first five years (1994-1999) of project, 
the prime emphasis was on the native and drought hardy vegetable crops such as kachri, snap melon, kakri, mateera, tinda and cluster bean. The chilli work for the Mathania type was taken in 1998 and then intensive initiatives on potential crops such as muskmelon, gourds, brinjal, beans and moringa was started from year 2000 considering requirement of superior genotypes for cultivation under the extremes of climatic variability. A mission mode approach for improvement in khejri was started in 2001. Trait specific breeding for heat tolerant in round melon, bottle gourd, muskmelon, tomato and brinjal was started from 2007. The systematic germplasm characterization and utilization at CIAH resulted to purification of promising and trait specific lines for detailed evaluation. Their-after the short-listed material was used in selection and combination breeding programme over the period (1996-2016) and this resulted to studies on about 725 developed genotypes in prioritized vegetables and potential isolates were further studied in varietal trials under high temperature, abiotic stressed and resources poor conditions of hot arid environment (Samadia et al. 2010; Samadia 2016; haldhar et al. 2018c). Systematic purification followed by selection and hybridization breeding at CIAH, Bikaner over the period of 25 years, a good number of high yielding and better quality producing genotypes are developed in arid vegetable crop-plants for commercial cultivation. The varieties recommended are in mateera (AHW-19, AHW-65 and Thar Manak), kachri (AHK-119 and AHK200), snap melon (AHS-10 and AHS-82), aryakakri (AHC-2), salad-kakri (AHC-13), tar-kakri (Thar Sheetal), bottle gourd (Thar Samridhi), sponge gourd (Thar Tapish), ridge gourd (Thar Karni), ivy gourd (Thar Sundari), palak (Thar Hariparna), brinjal (Thar Rachit), cluster bean (Thar Bhadavi), Indian bean (Thar Kartiki and Thar Maghi), sword bean (Thar Mahi) and khejri (Thar Shobha).
The unique lines of bottle gourd (AHLS24), ridge gourd (AHRG-1 and AHRG-8), sponge gourd (AHSG-4, AHSG-5 and AHSG-16), round melon (AHRM-1 and AHRM-2), muskmelon (CIAH-1), chilli (HRM-1), brinjal (CIAH-22) and moringa (AHMO-1-4s) were used in selection / combination breeding from 2001-2010 and advanced material is in large-scale testing at farmers fields / national net-work and further used in breeding programmes (Samadia 2008; Samadia 2012; Samadia 2016; Samadia \& More 2008; Samadia \& More 2009; Samadia \& More 2011; Samadia et al. 2005). In addition, some trait specific breeding material is developed in targeted crop-plants at CIAH, Bikaner and evaluated over the seasons and years (2005-2018) for their performance studies under high or low temperature, drought and abiotic stressed environment. These consisted of kachri (AHK411, AHK-564 and AHK-572), snap melon (DKS/AHS-2011/2), mateera (AHW RSS-1 and AHW BSM-1), kakri (AHC-1), ridge gourd (AHRG-15-4-1), bottle gourd (AHLS Oblong-1 and AHLS-Long/2015/F6/1), bitter gourd (AHBT2), chilli (Mathania Selection-1), brinjal (AHB-1 and AHB-2), tomato (AHSL-1 and AHSL-2), cowpea (AHCP-1 and AHCP-2), Indian bean (KSB-66), cluster bean (AHG-20), velvet bean (AHVB-1), paan-methi (AHLM-1), bathua (AHLB-1), carrot (AHDC-1), guarpatha (AHABS-1 and AHAB-B-1) and khejri (CIAH Selection2).

(c) Value-added genotype concept for developing arid vegetable crop-plant genetic material

In dry-lands of Rajasthan state, open-field vegetable production is under control of existing climatic and resources multiplicity. Systematic evaluation of a large numbers of crop-genotypes variability and varietal performance studies in targeted vegetables did not helped me in carving 
out most suited genotypes for cultivation recommendations with a set of environmental situations viz., abiotic stresses (high or low temperature, drought), rainfed, low-input, organic or drip technology. Besides, the genotypes developed else-where with to some extent similar agro-climate zone of the country are not as such suitable for cultivation at the situations given above under the dry-lands. Therefore, based on crop genetic variability, characterization and utilization studies at Bikaner, I have framed a concept to spot-out the requisite materials for direct selection or use in combination breeding and thereby developing varieties for commercial cultivation under a set of environmental situations and naming - value-added genotype. To develop value-added genotypes in dry-land vegetables, four criteria were taken in to the consideration as meticulous attributes of the breeding materials in the form of tolerant isolates under abiotic stresses situations or crop production requirement at defined set of environment site / zone in particular. These attributes are (i) more numbers of marketable quality fruits, pods or produce/plant (ii) earliness to first harvesting of produce as early maturing (iii) prolong period of harvesting as more numbers of pickings, and (iv) better yields with short duration of harvesting season.

For spotting-out of desired landraces, local-types, varieties or breeding lines, first of all, a large numbers of vegetable crops germplasm variability was evaluated over 2 to 3 seasons cycle and material was short-listed based on ranking using four meticulous attributes on 5 points-scale. Simultaneously, potential isolates were used in direct performance studies or specific combination breeding for a set of environmental situations as targeted. Adopting this technique, a wide-range of crop-genotypes selected and varieties developed at Bikaner and listed in utilization of arid vegetable germplasm (b) above. These are most designated material and can be used in combinations, segregating and re-structure breeding or value-addition of specific genotype to solve the problems of varietal requirement for a set of environment as targeted. In addition, a good numbers of high ranked crop-genotypes viz., watermelon (Sugar Baby, Durgapura Meetha, Arka Manik), muskmelon (Punjab Sunhari, MHY3, MHY-5), bottle gourd (Pusa Naveen), cowpea (RCV-7), Pea (RP-3, Azad Pea-1), Cabbage (Quisto), tomato (ARTH-4), Brinjal (Pusa Bindu, Pusa Kranti, Pusa Uttam, Pusa Rituraj, PPC, AB1), onion (N-53, Udaipur-101, Udaipur-102) were found most suitable for dry-lands. Besides, popular types and land-races of mateera (Bhadaan Local), ridge gourd (long-fruited types of Vaagad and Mewar area), onion (Local types from Sikar, Nagour, Jodhpur, Vaagad, Maalwa and Nimaar areas), garlic (Local types from Haadoti and Maalwa area), early-cauliflower (Local types from Sikar), Paan-methi (Nagour) and chilli (HaripurRaipur, Mathania Selection, Tonk Local,) are traitspecific variability, exhibiting much scope to stabilize the material and it can directly be utilized to develop value-added genotypes for dry-lands of Rajasthan.

\section{(d) Priorities for germplasm utilization and focus on future thrust}

Primarily I am working on the native crop-plants to promote horticultural production under water-deficit, environmental restrictions and resource poor production sites of dry-land. Therefore, the foremost concern is on their safe conservation, maintenance and effective utilization of genetic material for developing need-based varieties. In addition, developing suitable vegetable cropping sequence of kachri, kakadia, mateera, tinda, gourds, cluster bean and cowpea production with khejri models is of great significance. Besides, developing appropriate breeding material and trait-specific lines / valueadded genotypes through germplasm use in the 
prioritized vegetable crop-plants is in the top priority for promoting their cultivation under abiotic stresses viz., high temperature, drought, scanty rains or minimal irrigation water, and also suitability of varieties for organic, year the round or prolonged period of harvesting under the drylands of Rajasthan.

Crop breeding for improving yield, maturity, quality and produce acceptance is a continuous nature of work-plan for maximizing resources productivity and combating towards climatic factors. In addition, varietal requirements for three environmentally distinct climatic zones of Rajasthan and continual increasing demand of vegetable produce invites planned up-gradation and re-setting of research prioritization. Realizing the need of $21^{\text {st }}$ century, vegetable breeding programme should be focused on prioritized dryland crops and attention should be through intensive use of germplasm variability and existing / old varietal-wealth for developing trait-specific varieties and value-added genotypes and it is in particular for targeted zone of the state. Besides, objectives on prioritized and native crop-plants of commercial significance should be defined in respect to national and regional perspective. Based on the research progress and gap analysis in germplasm utilization and varietal development in the last 70 years in Rajasthan, crop and traitspecific prioritized needs have been identified for further in-depth investigation and research strengthening to achieve targets on the issues highlighted based on constraints and strategies as given below.

\section{(i) Research constraints:}

1. Insufficient germplasm in most of vegetables and ignorance of old lines / varieties in breeding,

2. Low priority on germplasm utilization to solve the problems through combination breeding,
3. Low priority to native and un-common vegetables for region and resource specific research,

4. Lack of new high yielding genotypes with inbuilt tolerant to abiotic and biotic stresses,

5. Absence of basic research and promotion facilities to work on wild and related species breeding,

6. Low level of scientific interest to carry longterm research work-plan on native vegetables, and

7. Low interest to solve long-standing crop problems with advancement of science and technology.

\section{(ii) Research strategies:}

a. Utilization of national genetic resources to develop high temperature and abiotic stresses tolerant genotypes with better marketable fruit quality yield in round melon, bottle gourd, mateera, muskmelon, ridge gourd, sponge gourd, bitter gourd and tomato for commercial cultivation with varying agro-climate of the state,

b. Utilization of native land-races and local-types for developing high yielding and better marketable quality varieties or trait-specific / value added genotypes for cultivation under abiotic stresses conditions in kachri, kakadia, arya-kakri, tar-kakri, wanga-kakri, kakoda, kundru, kheera (chikan-kakri of tribal area), palak, paan-methi, khejri, sehjan, curry-leaf, guarpatha and others including leafy, roots, tubers (yam, aerial yam and sweet potato) as zonal vegetables for their regional promotion and quality preferences,

c. Utilization of national genetic material from favourable agro-climatic and their large-scale trials to identify environment, trait-specific and region matching genotypes in 
commercially viable crops (chilli, ginger, turmeric, garlic, onion and seed spices) in respect to hot arid to semi-arid and/or subhumid and tribal zones of Rajasthan,

d. Distant hybridization and breeding for developing viruses tolerating genotypes in watermelon and chillies for cultivation under abiotic and biotic stresses,

e. Utilization of native germplasm for developing suitable brinjal genotypes having good quality and marketable fruit yielding attributes with regional preferences and suitability for year the round cultivation under high temperature conditions, and tolerant to FSB,

f. Utilization of national genetic material and local-types to develop high and better quality pod yielding genotypes in potential vegetable legumes viz., cluster bean, cowpea, pea, Indian bean, sword bean and velvet bean for production under variable resources and stressed conditions, and also for organic cultivation,

g. Heterosis or combination breeding to develop genotypes resistant to fruit-fly infestation and viruses tolerating lines in bitter gourd, ridge gourd, sponge gourd and pumpkin for cultivation under semi-arid to sub-humid zones of Rajasthan state,

h. Conservation and use of native okra germplasm from tribal area of Rajasthan and near-by areas of Madhya Pradesh and Gujarat to develop genotypes for cultivation under low-input, organic and dry-land conditions,

i. Utilization of early cauliflower and carrot germplasm of hot arid zone, and onion and garlic material of semi-arid to tribal areas of north-west India for developing trait specific genotypes for dry-land situations, j. Utilization of national genetic material for breeding better quality and high yielding genotypes for low-cost protected cultivation and vertical harvesting in the prioritized vegetable crops under hot arid and semi-arid agro-climate of Rajasthan,

k. Utilization of regional, national or older genepool to develop genotypes for organic, lowinput or rainfed production, or use in breeding to develop better quality, moderate yielding or unique-traits genotypes for cultivation under extremes of temperature $\left(45-50{ }^{\circ} \mathrm{C}\right.$ and tolerating abiotic stressed or define set of environmental conditions in the prioritized vegetables of dry-land.

(iii) What is needed in dry-land vegetable research and development programme?

The history of vegetable research for varietal development and technological advancement in the state of Rajasthan is pathbreaking during the green revolution era and it was from Udaipur and Durgapura (Jaipur) horticulture departments. A good number of varieties in popular vegetables from crop-specific native genepool were developed, and their area and production increased in localized pockets of the state and it was primarily owing to seed-chain by public sector institutions. From the year 1990 onwards, state agricultural universities, its constituent colleges / horticultural departments primarily turned towards academic oriented information through higher education. The horticulture departments at Udaipur, Jobner, Bikaner, Jodhpur and Jhalawar of SAU's do not have any strategic or specific vegetable breeding programmes running on the prioritized or native crops to develop need based varieties of respective zones or climatic variability areas of the state.

The one vegetable centre of AICRP (VC) presently located at RARI, Jaipur is concentrating on prioritized crops as targeted under national net- 
work. The crop-varieties from this centre are mainly for favourable agro-climate and batter resources including water. The ICAR-Central Institute for Arid Horticulture is working on dryland vegetable crop-plants research and the prime objectives are towards conservation and utilization of native genetic resources, and as a result numbers of varieties recommended for promoting vegetable cultivation under high temperature, abiotic and water stressed conditions. In addition, a wide range of vegetable genotypes is recommended for zone $\mathrm{IV}^{\text {th }}$ of the country including Rajasthan state and largely are from IARI, New Delhi. Most of such crop-varieties preferring mild-climate for expressing their potentiality and are susceptible towards extremeness of environmental conditions. Due to the largest geographical area, Rajasthan state depicted climate variability within the distinct zones for resource based vegetable promotion, and therefore apposite zonal level varieties and its seed-supply chain is the urgent need.

The state has first-rate district-level government departments of agri-horticulture and KVK's but there is no sound or net-working programmes to ensured recommended vegetable crop-genotypes seed-planting material through their production and supply-chain at grower's sites of zone. Most of this state-level agencies involved in promotion or advisory services for vegetable cultivation. Much of present vegetable varietal seed-chain as available at the markets is of private and multi-national sector. The production sites of such genotype seed is located at favourable climatic situations in the country or abroad and thereby expressing low quality produce, yield and productivity levels of crop-variety under the high temperature, drought and abiotic stressed production sites of dry-land areas. Thus, appropriate action-plan is needed for intensifying dry-land vegetable farming, and the road-map is summarized as under:-
1. Developing scientific awareness among the curators / workers about the right crop-plants for germplasm conservation and utilization in respect to particular agro-climatic zone targeted, and scientist working stability should be 20-25 years as issue taken for research technology out-put,

2. Utilization of the short-listed gene-pool, native varietal wealth and generated material for developing pre-breeding material, traitspecific lines or value-added genotypes in targeted crops with 25 years of road-map, and seed-chain development for crop-variety-wise production system as zone targeted.

3. Mass-publicity to bring desired awareness among the producers about the right cropgenotypes and its integrated technology for their production sites through cluster approach,

4. Regularity in supply-chain of quality seedplanting material of recommended cropgenotype for zonal production sites as farmer's-agency linking system approach,

5. Establishment of four vegetable breeding stations at distinct climatic variability zones to full-fill the prioritized and native crop-plants genotype requirement in accordance to the production sites and existing resources of growers. In addition, inter-linking of the breeding stations with crop-commodity production sites growers and systems of targeted zones for regular seed-planting material supply-chain of the promoted varieties. For intensifying vegetable industry in dry-lands of Rajasthan state, the climatewise four distinct and crop-specific breeding stations should be in-between the area of the district-towns (a) Banswara - Pratapgarh (b) Summerpur-Pali (c) Kuchhaman-Nagour and (d) Fathehpur-Chomu. Besides, inter-linking of these proposed centres with KVK's, ATC's, 
regional and national centres working for vegetable promotion in the state of Rajasthan is also needed to execute crop-specific genepool conservation, maintenance and developing varieties and its seed-chain.

\section{References}

Anonymous. 1994-2018. Annual reports. National Research Centre for Arid Horticulture / Central Institute for Arid Horticulture (ICAR), Bikaner (Rajasthan) India.

Anonymous. 2005. Final report - NATP on sustainable management of plant biodiversity- Collection, evaluation and maintenance of arid horticultural crops. Cooperating centre of NBPGR, Central Institute for Arid Horticulture (ICAR), Bikaner (Rajasthan) India.

Khan, H \& Samadia DK. 2012. Variability and association studies in tomato germplasm under high temperature arid region. Journal of Horticulture Sciences, 7 (2): 194-198.

More TA \& Samadia DK. 2007. Prospect of horticulture in arid zone. In: Dryland Ecosystem: Indian Perspective. (ed. K.P.R. Vittal, R.L. Shrivastava, N.L. Joshi, Amal Kar, V.P. Tewari and S. Kathju), CAZRI and AFRI, Jodhpur, pp 149-167.

More TA \& Samadia DK. 2008. Breeding strategies for vegetable crops with special reference to arid region. In: Souvenir and proceedings of national seminar on opportunities and challenges of arid horticulture for nutrition and livelihood, CIAH, Bikaner. pp. 1-10.

More TA, Samadia DK \& Verma AK. 2018. Arid vegetables for economic empowerment of rural inhabitants. Souvenir paper : National Conference on Arid Horticulture for enhancing productivity and economic empowerment. ICAR-CIAH, Bikaner. Book-ISBN: 978-5124-998-6. PP 51-56.
Pareek OP, Vashishtha BB, Vishalnath, Samadia, DK \& Singh RS. 1999. Horticultural resources in Thar dessert. In: Natural resources in Rajasthan (eds. Anil Kumar, Rajesh Sharma and Madhu Sharma), SKRAU, Bikaner. pp 4-9.

Haldhar SM, Berwal MK, Samadia DK, Kumar R, Gora JS \& Choudhary S. 2018a. Biochemical basis of plant-insect interaction in arid horticulture crops: a scientific review. Journal of Agriculture and Ecology, 6: 1-16.

Haldhar SM, Kumar R, Samadia DK, Singh B \& Singh H. 2018b. Role of insect pollinators and pollinizers in arid and semi-arid horticultural crops. Journal of Agriculture and Ecology, 5: 1-25.

Haldhar SM, Samadia DK, Choudhary BR. 2018c. Biotic stress (Insect) of Cucurbits in Arid Region of Rajasthan: A Review. JOJ Hortic Arboric 1(4): 1-9.

Samadia D K \& Haldhar SM. 2017. Breeding strategies and scope of improvement in arid zone fruit crop-plant under abiotic stressed agro-climate: an analysis. Journal of Agriculture and Ecology, 4: 1-13.

Samadia DK, Khan H \& More TA. 2010.Varietal improvement for quality marketable yield in muskmelon under high temperature conditions of arid region. Abstract of paper In: Book of abstracts of $4^{\text {th }}$ Indian Horticulture Congress-2010. November 1821, 2010. New Delhi. III-131: 126 p.

Samadia DK. 2006. Performance of muskmelon genotypes under arid conditions. Indian Journal of Arid Horticulture, 1 (2): 24-27.

Samadia DK. 2007. Genetic variability and correlation studies in brinjal. Indian Journal of Arid Horticulture, 2 (2): 18-21.

Samadia DK. 2003. Genetic resource management for sustainable horticultural development in 
arid regions of India. In: Sustainable Resource Management (eds. B.B.S. Kapoor and Ali Ahemad), Madhu Publications, Bikaner (India). pp 163-173.

Samadia DK. 2007. Arid Vegetables. In: Under utilized and under exploited horticultural crops. Peter, K.V. (ed.), Vol. 2 New India publishing agency, New Delhi (India), pp. 153-174.

Samadia DK. 2007. Genetic variability studies in chilli germplasm under hot arid eco-system. Indian Journal of Horticulture, 64 (4):477478.

Samadia DK. 2007. Studies on genetic variability and scope of improvement in round melon under hot arid conditions. Indian Journal of Horticulture, 64 (1): 58-62.

Samadia DK. 2008. Evaluation of Indian bean genotypes under hot arid environment. Indian Journal of Arid Horticulture, 3 (2): 22-25.

Samadia DK. 2008. Improvement of vegetable crops for hi-tech production. Hi-tech production of arid horticulture, More et al. (ed.), CIAH, Bikaner, pp. 391-398.

Samadia DK. 2010. Genetic variability studies and scope of improvement in sponge gourd under hot arid agro-climate. Indian Journal of Arid Horticulture, 5 (1-2): 37-39.

Samadia DK. 2011. Genetic variability studies for improvement in bottle gourd under hot arid agro-climate. Indian Journal of Arid Horticulture, 6 (1-2): 15-18.

Samadia DK. 2011. Genetic variability studies in ridge gourd under arid environment. Indian Journal of Horticulture, 68 (2): 275 - 277.

Samadia DK. 2012. Thar Bhadavi-new cluster bean. Indian Horticulture, 57 (4): 15-16.

Samadia DK. 2014. Utilization of genetic resources of vegetable crops for varietal development under hot arid agro-climate. Chapter in compendium of short course:
Advances in water management and fertigation in fruit and vegetable crops of hot arid region in India (eds. Sharma et al.), CIAH: Bikaner. pp 189-193.

Samadia DK. 2016. Breeding strategies for enhancing vegetable production under environmental stresses of hot agro-climate. Book chapter In: Good management practices for horticultural crops. New India Publishing Agency, New Delhi, pp217-226.

Samadia DK. 2016. Horticulture based crop production site management approach (HBCPSMA) - an innovative concept for doubling farm income under dry-lands. Journal of Agriculture and Ecology, 1: 1-9.

Samadia DK. 2016. Innovative concepts, techniques and practices for managing vegetable culture under environmental stresses of hot sub-tropic climate. Book chapter In: Good management practices for horticultural crops. New India Publishing Agency. New Delhi, pp199-216.

Samadia DK. 2016. Thar Shobha: New khejri variety. Indian Horticulture, 61 (4): cover page back \& 12-13.

Samadia DK. 2018. Cultivating underutilized vegetables in arid region. Indian Horticulture 63 (4): 34-39.

Samadia DK. 2018. Doubling horticultural productivity under khejri based cropping models in arid environment. Book chapter: Horticulture in arid and semi-arid region (ed. by M. K. Jatav et al.), New India Publishing Agency, New Delhi pp 453 573

Samadia DK. 2018. Improving yield and income of arid vegetables. Book chapter: Horticulture in arid and semi-arid region (ed. by M. K. Jatav et al.), New India Publishing Agency, New Delhi pp 89-112 
Samadia DK. \& More TA. 2009. AHSB-1 for protein-rich diet in arid region. Indian Horticulture, 54 (6): 24-25.

Samadia DK. \& More TA. 2011. Thar Manak to quench thirst in desert. Indian Horticulture, 56 (5): $14-15$.

Samadia DK \& More TA. 2008. New bottle gourd: Thar Samridhi. Indian Horticulture, 53 (2): 21.

Samadia DK \& More TA. 2009. New Indian beans for more protein-rich foods. Indian Horticulture, 54 (6): 20-21.

Samadia DK \& Haldhar SM. 2018. Strategies and advancement for improvement in arid vegetables. Indian Journal of Arid Horticulture, 13: 11-18.
Samadia DK. 2016. Conservation and utilization of gourd vegetable crop diversity for varietal development under high temperature and abiotic stresses of hot arid agro-climate. In: Abstract book of $\mathrm{I}^{\text {st }}$ International Agrobiodiversity Congress, Organized by Indian Society of Plant Genetic Resources \& Biodiversity International. November 6-9, 2016 New Delhi, India. 811 (P-237): p,163.

Samadia DK, Pareek OP \& Vashishtha BB. 2005. AHS 10 and AHS 82: New snap melons. Indian Horticulture, 50 (2): 10-11.

Samadia DK, Vashishtha BB \& Raturi GB. 2004. Prospects of vegetable production in the arid zone of India. In: Impact of vegetable research in India, Sant Kumar, P.K. Joshi. and Suresh Pal (ed.), National Centre for Agricultural Economics and Policy Research (ICAR), New Delhi. pp. 101-114. 